\title{
FORMATION OF BENEVOLENCE OF JUNIOR PRESCHOOL CHILDREN ON THE BASIS OF PERSONALITY ORIENTED INTERACTION OF THE EDUCATOR AND THE CHILD
}

\section{Tetiana Ponomarenko ${ }^{1}$ \\ Liudmyla Kozak ${ }^{2}$}

DOI: https://doi.org/10.30525/978-9934-588-53-2-22

\begin{abstract}
The aim of preschool education is the development of every child on the basis of formation of the fundamentals of its personal culture. The main component of the characterization of the personal culture is its interaction with society. Therefore, the skills of socially accepted behaviour and the ability to navigate in the world of human relationships are of great importance. Unfortunately, the results of the analysis of pedagogical practice in preschool institutions indicate that young children of preschool age rarely show kindness in their relations with their peers. Teachers-practitioners sometimes transfer the methodology of moral education of older children to the educational process of younger ones, which affects adversely their development. In the practice of moral education, authoritarian methods of influence on children are sometimes observed. As a result, the children have negativity, loss of initiative and activity. Therefore, the problem of formation of benevolence of junior preschool children on the basis of personality oriented interaction of the educator and the child is quite complex and insufficiently researched.
\end{abstract}

Subject of research: the method of formation of benevolence in relationships with peers on the basis of the usage of positive proactive assessment and individual discussions by the materials of plot drawings as methods of personality oriented interaction of an adult and a child.

The purpose of the study is to study the peculiarities of formation of benevolence of junior preschool children to peers on the basis

\footnotetext{
${ }^{1}$ Doctor of Pedagogical Sciences, Professor, Professor of the Department of Preschool Education, Kyiv University after Borys Grinchenko, Pedagogical Institute, Ukraine ${ }^{2}$ Doctor of Pedagogical Sciences, Associate Professor, Professor of the Department of Preschool Education, Kyiv University after Borys Grinchenko, Pedagogical Institute, Ukraine

(C) Tetiana Ponomarenko, Liudmyla Kozak
} 
of a personality oriented model of interaction between the teacher and the child.

The study: 1) the importance of moral education of junior preschool children, the urgency of formation of the beginnings of their social and moral competence and such an aspect of the designated competence as benevolence in relationships with peers are determined; 2) the importance of personality oriented interaction of the teacher and the child as a condition for effective moral development of preschool children is revealed; theoretical and methodological of fundamentals of the problem of formation of benevolence to peers on the basis of personality oriented interaction of the teacher and the child are studied; 3 ) the scientific base for the possibility of the solution of the investigated problem is underlined; 4) the essence and peculiarities of usage of positive proactive assessment in the educational process of preschool educational institutions and individual discussions by the materials of plot drawings as methods of personality oriented interaction of an adult and a child are studied; 5) the levels and features of development of benevolence of four year old children on the basis of specially elaborated author method of ascertaining experiment are revealed; 6) the effectiveness of formation of benevolence on the basis of the usage of positive proactive assessment and individual discussions by the materials of plot drawings as methods of personality oriented interaction of an adult and a child are experimentally tested and proved. In our opinion the problem of formation of benevolence in relationships with peers on the basis of a personality oriented interaction of an adult and a child in different periods of preschool childhood requires further research.

\section{Introduction}

Modern domestic education of preschool children is personality oriented. The aim of preschool education is the development of every child on the basis of formation of the fundamentals of its personal culture. A key component of the characterization of culture of a personality is its interaction with society, acquisition of moral values, knowledge, actions, behaviour and feelings. Thus, the Basic component of preschool education (Bazoviy komponent doshkilnoyi osviti, 2012) emphasizes the need to develop children's skills of socially accepted behaviour, the ability to navigate in the world of human relationships, the willingness to empathize and empathize with others. 
Modern society with its speedy dynamics, density of information space, constant changes, social and economical and technological innovation challenges a personality a lot, including the most important one - the ability to adapt quickly, safely and constructively to it. Therefore, it is extremely important from an early age to develop this child's ability, the ability to understand the social environment and to live in harmony with it.

At the same time, there is a contradiction in the theory and practice of preschool education between the formal and declarative recognition of a person as the most important value of society and the real, not always humane attitude of society towards it and the people towards each other. Thus, one of the main objectives of preschool education is to educate humanity, benevolence and formation of humane relationships of preschool children.

However, in absolute recognition of the importance of child's acquisition of social experience as a necessary condition of its personality development, it should be noted that the issue of teacher's impact on children in the process of moral education is polemically urgent.

In the conditions of a modern preschool institution, the teacher has the opportunity to approach differently the selection of means, forms and methods of pedagogical influence on children. To achieve some progress allows his orientation on solving the tasks of humanization of the educational process. The rejection of the authoritarian style of child management allows for significant advances in the child's moral development.

Unfortunately, in the practice of moral upbringing, there are sometimes authoritarian methods of influence on children - threats, orders, warnings, instructions, punishments, notations, prohibitions, negative assessment of the child's behaviour. As a result, the children have negativism, loss of initiative and activity.

The authoritarian child management is opposed by the personality oriented model of education, personality oriented interaction of the teacher and the child, which is based on the recognition of the self-worth of childhood, the ability of the adult to see and accept the child's inner world. Moral education of children with personality oriented approach implies their focus on acceptance and understanding another person, development their ability to identify themselves with other people. The sole functioning of the cognitive, behavioural and emotional processes in the moral development of the child by this approach is one of the main tasks. 
Vyhotskyi L. (1986), exploring the problem of personality, wrote about the unity of «affect and intelligence», that is, emotions and consciousness in the development of personality. The realization of such a position is possible in the act of moral choice, which is always based on the children's notions of good and evil and the emotional attitude to this knowledge. Therefore, the activity of the teacher should be focused on the search and use of such pedagogical influences that cause the «encounter of intelligence and affect» in the act of moral choice of the child, which is the culminating point of pedagogical influence. We consider this approach to the moral education of preschool children relevant and fundamental.

Unfortunately, our observation of the behaviour of children showed that children rarely show kindness in relationships with peers. Educatorspractitioners often transfer the methodology of moral education of older children to the educational process of younger ones, which affects adversely their development. Therefore, the problem of formation of benevolence of junior preschool children on the basis of personality oriented interaction of the educator and the child is quite complex and insufficiently researched.

The aim of the research: to study the peculiarities of formation of benevolence of junior preschool children on the basis of personality oriented interaction of the educator and the child.

Objectives of the research:

- to research theoretical and methodological fundamentals of the problem of formation of benevolence towards peers on the basis of personality oriented interaction of the educator and the child;

- to study the essence and peculiarities of the usage in the educational process of the institution of preschool education of positive proactive assessment and individual discussions by the materials of plot drawings as methods of personality oriented interaction of an adult and a child;

- to identify the levels and peculiarities of the development of benevolence towards peers of four year old children based on the use of individual discussions; solving verbal situations of moral choice with motivation for their decision; observing the behaviour of children in the conditions of different spheres of their life;

- to test experimentally the effectiveness of formation of benevolence towards peers based on the usage of positive proactive assessment and 
individual discussions by the materials of plot drawings as methods of personality oriented interaction of an adult and a child.

\section{Person-oriented formation of kindness in preschoolers.}

It is proved that childhood is a favourable age period for moral development of the child. A number of studies have examined the problems of theory and practice of moral education of children of preschool age: the development of children of moral and volitional qualities in the institution of preschool education (Bure R., 1986); the development of moral feelings of senior preschoolers (Vynogradova A., 1989); the content and organization of communication of preschool children as a way of moral education (Artemova L., 1985); the formation of humane relationships of senior preschoolers (Honcharenko A., 2003); the formation of benevolence of senior preschool children (Ponomarenko T., 2016); the development of humane feelings of preschool children (Pirozhenko T., Ladyvir S., Manyliuk Yu., 2010); the essence and peculiarities of social development of preschool children (Ponimanska T., Dychkivska I., Kozliuk O., Kuzmuk L., 2013); the essence and piculiarities of socialization of children of preschool and junior school age (Bogush A., Varianytsia L., Havrish N., Kurinna S., Pechenko I., 2006).

The summary of results of the analysis of a number of studies (Amonashvili Sh. (1990); Bekh I. (2003); Sushchenko T. (2011); Khutorskyi A. (2002), etc.) gives us an opportunity to state (Ponomarenko T., 2017: 33) that personality oriented educational process is a fullfledged emotionally rich and socially meaningful, cooperative and creative life of the teacher and the students that meets their basic social needs. The purpose of the personality oriented educational model is to discover and develop the individuality of every person on the grounds of formation of the basis of his or her personal culture. In the process of personality oriented education considerable attention is paid to the personal (subjective) experience of a person that becomes the subject of careful and thorough study for the teacher and serves him as a necessary support in educational activity. In other words, the educational process on the foundations of a personality oriented approach does not constitute a system of organized, rigidly normalized pedagogical influences on the individual, which ignore his or her willpower and cause psychological pressure on him or her. The basis of such an educational system is 
personal interaction, which is based on the teacher's compassionate attitude towards the students.

So, the results of analysis of theoretical base of formation of benevolence of junior preschool children towards peers on the basis of personality oriented interaction of the teacher and the child reveals the existence of scientific base for the possibility of its further investigation and solution.

It is proved that a child is not born with personality, it is needed to be developed in a child (Lieontiev O., 1985). The formation of a child's personality begins with the first years of his life (Vyhotskyi L., Elkonin D., Lieontiev O., Rubinstein S., etc., 1985).

One of the important results of a full-fledged development of the individual is the acquisition of social and moral competence in the totality of its components (cognitive, activity, emotional). The development of such forms of activity as emotional (susceptible to events, being able to feel other people's moods, able to restrain negative manifestations in the presence of outsiders, etc.) indicates the presence of social and moral competence in a four year old child within his or her age possibilities; social - sociable, responsive, being interested in adults and peers, being open to contacts, friendly, etc.; moral - being aware of elementary moral rules and norms of behaviour, trying to do right, having a desire to please, etc. (Kononko O., 2006).

Humanity is a basic quality, it is a feature of social and moral competence of the individual. While realizing the task of moral development of junior preschool children in our research, we paid our attention to the development of such an aspect of the defined competence as the formation of benevolence of four year old children in the conditions of a preschool institution.

The concept of «benevolence» is multifaceted by its content and form of manifestation in the relationships of preschoolers, associated with a number of other qualities. In the programmes of education and development of preschoolers the essence of the concept of benevolence is defined in a generalized form, and its manifestations are not clearly specified. As a rule, the most common forms of manifestation of the studied quality are distinguished. For example, attention is paid to the need to develop the ability of preschoolers to show mutual support, friendliness, responsiveness and attention to adults and peers. Certainly, it is difficult for the children to understand the essence of such rather abstract concepts as to be attentive, friendly and sensitive to the others, etc.. Therefore, we identified definite 
forms of benevolent behaviour that are available for conscious acquisition by the children, such as: helping their peers; taking care of him if he is either uncomfortable or he is in the situation of physical or moral discomfort; sharing something with him; yielding; not offending him; feeling sorry for him, etc. (Ponomarenko T., 2016).

Modern educational process in groups of four year old children is mainly focused on group forms of work in accordance with outdated standards. However, significant individual differences, psychological and physiological peculiarities of children make it necessary to introduce a person-centred model of an individualized educational process. It is important for teachers of groups of junior preschoolers to provide «conversational format of interpersonal interaction of a teacher and the children» (Havrysh N., 2018: 9). The prevalence of individual forms of pedagogical work with children, the organization of their interaction should provide comfortable, emotionally-positive rhythm and pace of life for each child (Havrysh N., 2018).

For the development of the individuality of a junior preschool child one must apply methods that make the child feel optimistic and happy, be in a good mood, provide the ability to act independently and make simple decisions, contribute to the development of basic self-assessment and confidence, form the ability to be pleasant, raise interest and respect for other people (Kononko O., 2006).

One of such methods is a pedagogical assessment. It plays a significant role in moral development of the child, especially a junior preschool one, due to its emotionality.

It has been proved (Kosheleva A., Strielkova L., Roiak A., Titarenko T., Pimenova L., etc., 1985) that the psychological impact of a positive assessment consists of the child's experience of joy and pleasure caused by its efforts, diligence and successes achieved. Positive assessment promotes an outburst of vigour, energy and self-belief, it increases the desire to act positively, to carry out socially approved actions, it influences the development of the emotional sphere of children, it develops a sense of dignity and will, it forms confidence in the success of the activity. Approval makes the child feel a sense of emotional well-being and a joyful experience. Adults' condemnation and their dissatisfaction contributes to the appearance of unpleasant experiences. 
The child forms the assessment of its own actions and qualities under the influence of different types of evaluation (approval, gratitude, complaining) and adults' manifestation of respect or dissatisfaction. The feelings that show children's attitude to certain people (affection, sympathy, empathy, dislike, etc.) are developing. The personality is being developed in this very period (Smolnykova H., 2018).

Using assessment effects, the teacher should take into account the condition of the child, the degree of its adaptation to the assessment, the nature of needs, intentions, interests, the peculiarity of the situation in which the child is, its reaction to the assessment impact and experience, because the reaction to the assessment is one of the indicators of its degree of exposure.

However, the assessment becomes a guide for a child only if the adult acts as a model of empathy and humanity, establishes emotional contact with the child, shows a willingness to come to the aid and attention to its experiences. The argumentation of assessment impact is also necessary, as the children perceive each case specifically and evaluate it from the standpoint of known norms of morality.

The impact of pedagogical assessment on children of the fourth year of life can hardly be exaggerated. The assessment is used for the formation of positive actions of children, their correction, the development of moral consciousness and emotional sphere. The assessment is considered to be one of the most effective methods of resolving numerous conflicts, because it is an obligatory condition for the child's mastering the rules of conduct and the condition for child's acquisition of morally useful habits.

Therefore, a special attention should be given to the usage of direct assessment in the educational process of the institution of preschool education, which is used as one of the methods of development of primary features of collective activity. Thus, the usage of positive and negative assessment impact is an effective condition for the formation of children's ideas about how to act in the process of communication with peers. Due to the assessment impact, the information that children need to know and their actions take on an emotional and expressive colouring. However, it is important to understand that direct assessment has a more effective impact on junior preschool children, whereas indirect assessment often becomes more effective for senior children. 
The psychological and pedagogical position on the role of positive assessment that contributes to the first beginnings of feeling of pride and negative - as a condition of feeling of shame of children of the fourth year of life is of great importance. It has been proved (Zaporozhets O., Lieontiev O., Rubinshtein S., Neverovych Ya., etc., 1985) that under assessment stimulation the children learn successfully ethical information, the actualization of which is observed in their real actions. The adult's high assessment of the child's positive qualities arouse the desire to have these virtues, which create favourable internal conditions for the practical mastery of certain qualities. At first, the children, trying to meet their own needs for positive assessment, begin to feel proud of their skills and qualities even before they have mastered them sufficiently. In this regard, the usage of positive proactive assessment in the educational process and in the moral education of junior preschoolers in particular is of paramount importance.

It is proved that positive proactive assessment actualizes cognitive function because it carries ethical information that needs to be learned by the child. It also has a prescriptive function, defining subsequent actions of the child, as well as stimulating their implementation. The attribution of success in the activity leads to positive actions. Positive proactive assessment expresses the educator's judgement about the child, that is, it is personal. The teacher, positively assessing the qualities of the child, makes him feel an emotional and positive state.

The method of using individual discussions by the materials of plot drawings for formation of benevolence of junior preschoolers on the basis of a personality oriented model of interaction of an adult and a child was also developed and introduced in the educational process of a preschool educational institution (Ponomarenko T., 2016). At the same time, we have taken into account that the preschoolers are able to perceive the content of pictures and illustrations where the characters perform no more than two or three actions. It is difficult for them to be aware of a composition that includes many characters, objects or actions. The variety of compositional elements diverts the children's attention from understanding the idea of the drawing, its moral and emotional content. When discussing the essence of such a picture, preschoolers often begin to fantasize, focusing on any detail. The children can describe the plot of the drawing in detail, if it is close enough to their life experience. 
The success of individual discussions based on the materials of the plot drawings is also determined by their brightness and dynamism. The image of the objects should be simple, clear and without unnecessary details. In such circumstances, junior preschoolers are able not only to understand the content of the plot of drawings. The children emotionally perceive images of individual characters - they consider carefully their poses and the expression of their faces. As a rule, the children's attention is attracted by the actions of heroes (running, sitting, standing, crying, helping, etc.) in the picture. Gestures, postures, facial expressions often go unnoticed. They are perceived by children only if they are vividly portrayed (running tears, being rubbed with a handkerchief, etc.). That is an important factor that determines the attitude of the child to these characters is the expressiveness of the picture.

This makes it easier for children to perceive the emotional state, which is expressed directly in the facial expressions of the portrayed characters. The perception of emotional experiences that are actualized in the poses, gestures, pantomimes of heroes is difficult enough for junior preschoolers. It is also difficult to perceive the sad mood of heroes, as the mimic of sadness is transmitted by little and unnoticed strokes. The facial expressions of joy and anger are more easily perceived.

The statement that at junior preschool age children are able to understand not only the external, plot aspect of an artistic image, but also its deep emotional content is very important for our research. It is proved that the inner emotional essence of the depicted phenomena is understood by a young child even when even the plot of the picture is not clear enough for her or him and she or he is unable to convey it with words.

In the context of our study it is also important to realize that paying the children's attention to the pose, the position of the characters in space, their gestures and facial expressions greatly simplifies the perception of the internal state of the characters of the drawings, which causes appropriate emotions of the children and promotes the expression of feelings.

Thus, the results of the analysis of the special literature indicate that the teacher's awareness of the peculiarities of the young child's perception of the drawing content, as well as the use of methods of activating the attention of children on the experiences, moods, emotional state of the heroes contribute not only to the children's understanding of the moral information embedded 
in the content of the drawings, but cause the formation of empathy, compassion, actualization of various forms of benevolent behaviour.

\section{Research of personality-oriented formation of kindness in preschool children}

An empirical study was conducted on the basis of the analysis of the results of studying the theoretical fundamentals of the researched problem. The study involved 127 children of the fourth year of life.

The author's method of ascertaining experiment was developed within the research to identify the level and characteristics of four year old children's benevolence to peers. Individual discussions; solving verbal situations of moral choice with motivation for their decision; observing the behaviour of children in the conditions of their various activities were used as methods of scientific pedagogical research.

The peculiarities of preschoolers' moral perceptions of benevolence towards peers were revealed on the basis of the use of individual discussions and the solution of verbal situations of moral choice with the motivation of their own choice. During the conversation the children were asked to answer the question "What does it mean to be a good child? A good child - what kind of a child is it?".

For solution the children were offered verbal situations of moral choice of such content.

Situation 1. The children have come to kindergarten this morning. Some of them have brought cookies, candies and apples from home. Only Maxim is standing alone and weeping bitterly.

- Why are you crying? - asks the teacher.

- I’ve lost my candy, - replies Maxim.

What will the children do?

Situation 2. The children were playing in the playground. Mariia fell and grazed her knee. She is crying. What will the children do?

Situation 3. Myshko and Petryk were playing with toy cars. Petryk's car broke down. How will Myshko act?

The analysis of the results of individual discussions and the solution of verbal situations of moral choice allow us to state that the level of development of moral ideas of four year old children about benevolence towards peers was different. Depending on this all the children were divided into three groups. 
To children with sufficient level of development of moral ideas were referred the children, whose answers show the understanding of the essence of the researched concept in accordance with the forms of its manifestation defined by us. In the answers to the question "What does it mean to be a good child? A good child - what kind of a child is it?" they named all outlined by us in accordance with the scientific definition of forms of manifestation of benevolence in relationships with peers (that is the child who helps, cares, concedes, shares, regrets, does not offend, etc.); these children also adequately solve all the situations of moral choice and motivated their decision, that is they answered the question «Why do you think so?». In the motivation of their solutions of the situations there is a focus on the difficulties of characters' situations, their negative emotional state about this.

To the group of children with not quite sufficient level of development of moral ideas about benevolence were included children who called more than a half defined by us in accordance with the scientific definition of forms of its manifestation; these children also appropriately solved most of the (two out of three) situations of moral choice and motivate their solution. In the motivation of their solutions of situations there is not always a focus on the difficulties of characters' situations, their negative emotional state about this. Sometimes there is a focus on some actions of the characters of the situations, etc.

The group of children with insufficient level of development of moral ideas were referred the children who called less than a half defined by us in accordance with the scientific definition of forms of manifestation of benevolence or inadequately identified them or not defined at all (i.e., there was no answer); these children adequately solved the smaller part (one out of three) of the situations of moral choice or solved none. In the motivation of their solutions of situations there is not always a focus on the difficulties of characters' situations, their negative emotional state about this. Sometimes there is either a focus on some actions of the characters of the situations or the absence of motivation of their solutions .

In the ascertaining part of the experiment the results of observing the behaviour of children in different types of activities were also analysed. Based on the analysis of the results of the observation, the children were divided into the following groups. The first group includes the children who often show benevolence and good deeds towards peers. The second group includes the children who only occasionally show benevolence and 
sometimes commit moral acts towards peers. The third group includes the children who often show ill-will towards peers and their behaviour is characterized by negativism.

The generalization of the results of the ascertaining experiment allowed us to refer to a sufficient level of development of benevolence towards peers the children who have a high level of development of moral ideas about the nature of the researched concept and they frequently show benevolence towards peers and commit moral acts.

To the not quite sufficient level of development of benevolence we refer the children with a high level of development of moral ideas about the researched concept but only sometimes they show benevolence towards peers фтв вщ positive actions; the children who have a medium level of development of moral ideas about the nature of the concept under study and only occasionally show benevolence towards their peers were also referred to the defined level.

To the insufficient level of development of benevolence we refer the children with medium level of development of moral ideas about the nature of the studied concept, but who often show hostility towards their peers and whose behaviour is characterized by negativity; as well as children who have a low level of development of moral ideas about the nature of benevolence and who often show ill-will in relationships with peers and whose the behaviour is characterized by negativity.

The quantitative ratio of the levels of development of benevolence in peer relationships of junior preschool children is presented in Table 1.

Table 1

The quantitative ratio of the levels of development of benevolence in peer relationships of junior preschool children

\begin{tabular}{|c|c|c|}
\hline \multicolumn{3}{|c|}{$\begin{array}{c}\text { The number of children who have the level of development } \\
\text { of benevolence in peer relationships }\end{array}$} \\
\hline sufficient & not quite sufficient & insufficient \\
\hline 6 & 54 & 67 \\
\hline
\end{tabular}

Thus, the results of the study indicate that the sufficient level of development of benevolence towards peers was detected in six children of the fourth year of life; not quite sufficient - in fifty-four children; insufficient - 
in sixty-seven junior preschoolers. The results confirm the need for the formation of benevolence towards peers of junior preschool children.

Based on the above, we have offered to introduce in the educational process of preschool educational institution specially elaborated by us author's methods such as the method of using positive proactive assessment in the process of spontaneously challenging situations of interaction between junior preschoolers, both friendly and unfriendly, as well as in specially organized situations of interaction; the method of individual discussions by the materials of plot drawings.

In the process of a specially organized situation, as well as in solving every situation that arises spontaneously, a positive proactive assessment promotes children's learning about friendly relationships with peers, the formation of experience of good deeds on the basis of actualisation of the information being learned. In this case, a positive proactive assessment promotes a child's sense of pride of such a quality as benevolence attributed to him by an adult, though often it has not been formed yet, which leads to the successful acquisition of ethical information and the formation of real displays of benevolence, which acquire a positive emotional colouring.

Thus, positive proactive assessment is used as a method of the formation of ideas about friendly relationships between peers of junior preschoolers, experience of real deeds of kindness, corresponding to these ideas and the development of the emotional sphere of the child.

Here are some examples of the usage of positive proactive assessment in the process of organization of situations of moral choice.

The children are going for a walk. Katia begins to cry quietly. None of the children is paying attention to her. Volodia is dressing up near the girl. The teacher addresses him: «Volodia, why do you think Katya is crying?» The boy looks at the girl and shrugs his shoulders. Teacher: "Katia is homesick, she has been ill for a long time and she cannot get used to the kindergarten. I know that you are a good and kind boy, you always help children, you feel sorry fir them when they are bad, you reassure them, you take care of them, you can sooth them and say a good word. Volodia nods and comes to Katia. He starts stroking her head. However, Katia continues crying. Volodia looks at her and the teacher curiously. Teacher: «Can you help her to dress up?» Volodia tries to help the girl. Katia stops crying. She is smiling now. The children hold hands and go out for a walk together. 
Thus, in the process of organizing the situation, the teacher informs the child of the ways of showing kindness to a peer - to help, to take care, to calm down, to feel sorry, etc. The teacher shows confidence that the child is good and kind. The child will always help others when it is necessary. Thus, without pressure and demands, the teacher encourages the child to show kindness. At the same time, the encouragement of an adult does not have the form of an imperative and authoritarian management of the child, teacher's encouragement contributes to cooperation with the child. At the same time, the information received by the child and its real manifestations of kindness have a positive emotional colouring. The child feels proud of adult's approval and acts confidently in relationships with peers.

It should be noted that a positive proactive assessment should be used together with the techniques of teacher's verbal description of a peer' difficulties and his negative emotional state in challenging situations, as well as his positive experience in situations of success and comfort. The description of the attractiveness of real displays of child-friendliness and a direct positive assessment of their actions are also used.

Positive proactive assessment should also be used to correct the behaviour of children when they behave unfriendly. This kind of assessment impact can be used to prevent unfriendly deeds of the children. It is important to be able to use positive proactive assessment at different time intervals, both for individual impact on the child and for the whole group of children. The organization of situations through positive proactive assessment in independent playing activities needs special attention. The observation of emotional state of preschool children during playing activity has shown that some of them feel depressed and lonely. They are more likely to communicate with adults than with children. A great number of four year old children find it difficult to get on well with their peers.

The analysis of the theoretical fundamentals of the problem under study and the results of the ascertaining experiment led to the development of a method of using discussions by the materials of plot drawings in order to form junior preschool children's benevolence. In discussions we took into account that benevolence and ill will are generalized concepts that contain some meaning. During the discussion the child had the opportunity to come to the conclusion through the example of specific alternative actions of the heroes what it means to be kind to peers, to learn about the forms of 
manifestation of benevolence, to find out how a benevolent act differs from a malicious one.

The children had two series of individual discussions by the drawings. Ten pairs of pictures were used in the first series of discussions. Every pair of pictures had selected scenes in which the kind hero shows the ability to care for their peers, to help them, to feel sorry for them when they feel bad, to share with them, to yield and not to offend. The bad character showed the opposite unfriendly actions. For example, the plots of the paired drawings were as follows. The content of the first pair of drawings: the boys are playing with a ball, one of them falls down, grabs his knee and starts crying, the other two start regretting him, one of them is wiping his tears with a handkerchief, the other one is stroking his head; the boys are playing with a ball, one of them falls down, grabs his knee and starts crying, the other two do not pay attention to him and continue to playing. The content of the second pair of drawings: the boy is holding out an apple to the girl treating her; the boy hid an apple behind his back and he does not want to treat the girl and so on.

The technique of having individual discussions by the pictures was as follows. The child was given an opportunity to look at a couple of drawings. We found out if the child could understand the plot of each picture. Then the child was offered to answer the questions about what character he or she liked - in the first drawing (good) or in the second (bad) and to motivate his or her choice.

It should be noted that the method of having discussions was determined by the level of development of child's ideas about the friendly attitude to peers, that is, it depended on which character the child chose (benevolent or not benevolent) and how he or she motivated his or her own choice. Thus, an adequate choice of the hero (good) and its motivation by his benevolence was considered as the evidence that the child not only understands the content of drawings at the level of actions of the characters, but the child is also aware of his emotional and moral content.

We consider it appropriate to give an example of such an individual discussion. Thus, the child was offered to look at the two drawings: the content of the first - a boy, who had been playing with a ball, fell down and injured his knee, the other two put a bandage on his injured knee and helped him to sit on the bench; content of the second drawing - a boy, who had been 
playing with a ball, fell down, grabbed his injured knee and started crying, the other two boys did not pay attention to him and continued to playing with a ball. The child chooses the characters in the first picture. When the child is asked by the teacher why she has chosen them, she replies: "The boys have pitied their friend." Teacher (T): "What are the boys? What can they be called?" Child (Ch): "Good and kind." T.: "What do you think these good boys could still do for their friend?" Ch.: "They could put some iodine on the knee and take the boy to his mother." T.: "Right, what else? Do you think they could smile at the boy and say good words?" Ch.: "Yes, they could." T.: "What would they say to the boy?" Ch.: "Do not cry, everything will pass, the leg will not hurt soon and they could stroke his head." T.: "Why do they do this?" Ch.: "Because they are kind." T.: "Why didn't you like the boys in the other picture?" Ch.: "They did wrong, they are evil and bad."

In the process of individual discussions there were cases of children's choosing friendly characters, but the children were not able to motivate their choice. In cases where the motivation for adequate choice was absent or was not determined by the benevolence of the hero, the teachers necessarily focused the children's attention on the well-being of the character, in relation to whom the benevolence was manifested - on his mood and positive experiences. They attempted to explain the necessity of manifestation of benevolence by the results of positive actions of the characters of the drawings, in relation to whom the benevolent acts were carried out, very nice, they are smiling, rejoicing, feel comfortable and protected, etc..

Thus, in the process of having the first series of individual discussions by the drawings junior preschool children were offered on the basis of updating the principle of "polar standards" ("good" - "bad") to solve the situations of moral choice and to motivate their own choice in order to form emotionally mediated moral ideas of specific forms of manifestation of benevolence towards their peers and development of moral emotional states (compassion, empathy, etc.).

In the second series of individual discussions the children were offered to look at drawings, one part of which depicts preschool children getting into unfavourable situations (for example, a boy is going for a walk, he can not tie a scarf and he starts crying; the girl has been playing with a spade in the sand, the spade breaks down and the girl starts crying; the boy has fallen from his chair and starts crying, etc.). The second part of the sheet that was 
free from the picture was for putting the characters - the good and then bad ones, drawn and cut out of cardboard. The good boy was portrayed as affable and friendly. The bad boy's face was unkind and evil.

Therefore, in the process of individual discussions by the drawings the preschoolers solved the tasks of moral orientation at first on behalf of the good boy, which was the first part of the ethical task, and then on behalf of the bad one, which represented the second part. In addition, the children were offered to act out the solution of the first part of the task, that is, they were encouraged to direct. Thus, the children not only verbally solved the problem of moral content, but also acted it out, manipulating the figure of a good hero, commenting aloud on his actions.

It should be noted that in the process of independent play activity the children were given the opportunity to look at the drawings, which had previously been used in individual discussions, and to play with positive characters. Sometimes, when acting out the plots independently, the children asked where the bad boy was and asked the teachers to give them his figurine to play, but the teachers replied that the bad boy had bad deeds, so he should not be invited to the children.

Therefore, in the second series of individual discussions pedagogical work was continued on the formation of emotionally mediated knowledge of junior preschoolers about specific forms of benevolence towards peers. In addition, in the process of acting out the ways of solving tasks of ethical content, the actualization of the learned moral ideas in individual game activity was carried out, which contributed to the formation of the experience of their benevolent actions and moral activity.

The generalization of the results of the control experiment allowed us to determine the quantitative ratio of the levels of development of benevolence in peer relationships of junior preschool children, which is presented in table 2.

Table 2

The quantitative ratio of the levels of development

of benevolence in peer relationships of junior preschool children

\begin{tabular}{|c|c|c|}
\hline \multicolumn{3}{|c|}{$\begin{array}{c}\text { The quantitative ratio of the levels of development of benevolence } \\
\text { in peer relationships of junior preschool children }\end{array}$} \\
\hline sufficient & not quite sufficient & insufficient \\
\hline 18 & 71 & 38 \\
\hline
\end{tabular}


The analysis of the results of the control stage of the study indicates that eighteen children of the fourth year of life have shown a sufficient level of development of peer benevolence; not quite sufficient seventy one child; insufficient - thirty eight junior preschoolers. The obtained results confirm the effectiveness of the usage of positive proactive assessment and individual discussions by the materials of plot drawings as methods of personality oriented interaction of adults and preschool children in the educational process of preschool educational institution.

\section{Conclusions and suggestions}

Thus, the study determined the importance of moral education of junior preschool children, the formation of the beginnings of their social and moral competence and such an aspect of the designated competence as benevolence in relationships with peers. The importance of personality oriented interaction of the teacher and the child as a condition for effective moral development of preschool children is revealed. Theoretical and methodological fundamentals of the problem of formation of benevolence towards peers on the basis of personality oriented interaction of the teacher and the child are researched. The scientific base on the possibility of solving the problem under study is outlined. The essence and peculiarities of the usage of positive proactive assessment and individual discussions by the materials of plot drawings as methods of personality oriented interaction of the adult and the child in the educational process of preschool educational institution are studied. The levels and peculiarities of junior preschool children's benevolence towards their peers on the basis of specially developed author method of ascertaining experiment are revealed. The effectiveness of formation of benevolence towards peers on the basis of the usage of positive proactive assessment and individual discussions by the materials of plot drawings as methods of personality oriented interaction of the adult and the child is experimentally tested and proved. In our opinion, the problem of formation of children's benevolence towards peers on the basis of personality oriented interaction of the adult and the child in different periods of preschool childhood requires further research. 


\section{References:}

1. Amonashvili, Sh. A. (1990). Lichnostno-gumannaya osnova pedagogicheskogo protsessa [Personally-humane basis of the pedagogical process]. Minsk: Universitetskoe obrazovanie. (in Russian)

2. Artemova, L. V. (1985). Soderzhanie i organizatsiya obshcheniya doshkol'nikov kak sredstvo nravstvennogo vospitaniya [The content and organization of communication of preschool children as a means of moral education]. (PhD Thesis), Moscow.

3. DoshkIlne vihovannya (2012). Bazovyj komponent doshkiljnoji osvity [Basic component of preschool education]. Ofitsiyniy viddil, vol. 7, pp. 5-19.

4. Bekh, I. D. (2003). Vykhovannia osobystosti: u 2-kh kn. [The education of the individual]. K.: Lybid. Kn. 1: Osobystisno oriientovanyi pidkhid: teoretyko-tekhnolohichni zasady. (in Ukrainian)

5. Bondarevskaya, E. V. (2003). Lichnostno-orientirovannyy podkhod kak tekhnologiya modernizatsii obrazovaniya [A personality-oriented approach as a technology for the modernization of education]. Metodist, vol. 2, pp. 2-6.

6. Bure, R. S. (1986). Teoriya i metodika vospitaniya u detey nravstvenno-volevykh kachestv v detskom sadu [Theory and methodology of educating children of moral-volitional qualities in kindergarten]. ( $\mathrm{PhD}$ Thesis). Moscow.

7. Burkovska, O. (2020). Cilisnyj pidkhid do rozvytku i vykhovannja najmolodshykh [A holistic approach to the development and education of the youngest]. Doshkilne vykhovannia, vol. 6, pp. 10-12.

8. Pirozhenko, T., Ladyvir, S., \& Manyliuk, Yu. (Eds.). (2010). Vykhovannja ghumannykh pochuttiv u ditej [Education of humane feelings in children]. Ternopil: Mandrivets. (in Ukrainian)

9. Vinogradova, A. M (Ed). (1989). Vospitanie nravstvennykh chuvstv u starshikh doshkol'nikov. 2-e izd., ispr. i dop [Education of moral feelings in older preschoolers. 2nd ed., Rev. and additional]. Moskva: Prosveschenie. (in Russian)

10. Havrysh, N. (2018). Znajome nevidome pokolinnja, abo khto ty, maljuku? [Familiar unknown generation, or who are you fo the baby?]. Vykhovatel-metodyst doshkilnoho zakladu, vol. 10, pp. 4-10.

11. Honcharenko, A. M. (2003). Pedaghoghichni umovy stanovlennja ghumannykh vzajemovidnosyn starshykh doshkiljnykiv [Pedagogical conditions of formation of humane relationships of senior preschoolers]. (PhD Thesis). Kyiv.

12. Bohush, A. M., Varianytsia, L. O., Havrysh, N. V., Kurinna, S. M., \& Pechenko, I. P. (2006). Dity i socium: Osoblyvosti socializaciji ditej doshkiljnogho ta molodshogho shkiljnogho viku: monoghrafija [Children and society: Features of socialization of children of preschool and primary school age: monograph]. Luhansk: Alma-mater. (in Ukrainian)

13. Zaporozhets, A. V., Neverovich, Ya. Z., \& Kosheleva, A. D. (1985). Emotsional'noe razvitie doshkol'nika: posobie dlya vospitateley det. sada [The emotional development of a preschooler: a guide for educators det. the garden]. Moskva: Prosveschenie. (in Russian)

14. Kononko, O. (2006). Osobystisne zrostannja v rannjomu vici: sutj ta umovy spryjannja [ersonal growth at an early age: the essence and conditions of promotion]. Doshkilne vykhovannia, vol. 10, pp. 3-6. 
15. Ponomarenko, T. O. (2017). Teorija i metodyka formuvannja upravlinsjkoji kuljtury kerivnykiv doshkiljnoji osvity: monoghrafija [Theory and methodology of forming the managerial culture of preschool education leaders: a monograph]. Sumy: Vinnychenko M. D. (in Ukrainian)

16. Ponomarenko, T. O. (2016) Formuvannja dobrozychlyvogho vidnoshennja do odnolitkiv u ditej molodshogho doshkiljnogho viku [Formation of benevolence in young preschool children]. Visnyk «Pereiaslav-Khmelnytskyi derzhavnyi pedahohichnyi universytet imeni Hryhoriia Skovorody». Ad. 3 to the vol. 36. Vol. II (18): Vol. «Mizhnarodni Chelpanivski psykholoho-pedahohichni chytannia». Kyiv: Hnozys.

17. Ponomarenko, T. O. (2016) Formuvannja dobrozychlyvogho vidnoshennja do odnolitkiv u ditej molodshogho doshkiljnogho viku [Formation of benevolence in young preschool children]. Proceedings of the I Mizhnarodnoi naukovo-praktychnoi konferentsii Natsionalna osvita $v$ stratehiiakh sotsiokulturnoho vyboru: teoriia, metodolohiia, praktyka (Ukraine, Lutsk, April 14, 2016). Lutsk: Lutskyi pedahohichnyi koledzh.

18. Zaporozhtsa, A. V., \& Neverovich, Ya. Z. (Eds.). (1986). Razvitie sotsial'nykh emotsiy u detey doshkol'nogo vozrasta: Psikhologicheskie issledovaniya [The Development of Social Emotions in Preschool Children: Psychological Research]. Moskva: Pedagogika. (in Russian)

19. Kuzmuk, L. I. (2013). Rozvyvajemo, navchajemo, vykhovujemo dytynu tretjogho roku zhyttja : metodychnyj posibnyk [Develop, train, educate a child of the third year of life: a manual]. Kyiv: Vydavnychyi Dim «Slovo».

20. Smolnykova, H. (2018). Osoblyvosti rozvytku psykhichnykh procesiv u ditej rannjogho viku [Features of the development of mental processes in young children]. Palitra pedahoha, vol. 3, pp. 3-6.

21. Ponimanska, T. I., Dychkivska, I. M, Kozliuk, O. A., \& Kuzmuk, L. I. (2013). Socialjnyj rozvytok dytyny : starshyj doshkiljnyj vik [Social development of the child: senior preschool age]. Kyiv: Heneza. (in Ukrainian)

22. Sushchenko, T. I. (2011). Osoblyvosti osobystisno orijentovanogho pedaghoghichnogho procesu [Features of personally oriented pedagogical process]. Pedahohika i psykholohiia formuvannia tvorchoi osobystosti: problemy i poshuky, vol. 19, pp. 3-6.

23. Hutorskoy, A. V. (2002). Klyuchevye kompetentsii kak komponent lichnostno-orientirovannoy paradigmy obrazovaniya [Key competencies as a component of a personality-oriented education paradigm]. Moskva: IOSO RAO. (in Russian) 